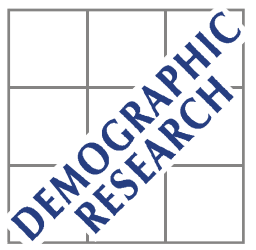

Demographic Research a free, expedited, online journal of peer-reviewed research and commentary in the population sciences published by the Max Planck Institute for Demographic Research Konrad-Zuse Str. 1, D-18057 Rostock · GERMANY www.demographic-research.org

DEMOGRAPHIC RESEARCH

VOLUME 12, ARTICLE 5, PAGES 105-106

PUBLISHED 22 MARCH 2005

www.demographic-research.org/Volumes/Vol12/5

DOI: 10.4054/DemRes.2005.12.5

Research materials

\title{
Quadratic spline fits by nonlinear least squares
}

Carl Schmertmann

(C) 2005 Max-Planck-Gesellschaft. 


\section{Table of Contents}

Abstract and URL 


\title{
Quadratic spline fits by nonlinear least squares
}

\author{
Carl Schmertmann ${ }^{1}$
}

\begin{abstract}
This web program fits a Quadratic Spline model, as described in Schmertmann (2003; Demographic Research Volume 9, Article 5), to any empirical fertility schedule supplied by the user. The fit minimizes the sum of squared differences between the empirical nfx values and the $\mathrm{nfx}$ values from the QS model schedule. Output includes parameter estimates, a graphical depiction of the fitted schedule, and several text reports. Users do not need specialized statistical software or a particular operating system to run the program; the only requirement is a web browser
\end{abstract}

http://www.demographic-research.org/Volumes/Vol12/5/qsfit/qsfit.html

${ }^{1}$ Florida State University. E-mail: schmertmann@fsu.edu 
Schmertmann: Quadratic spline fits by nonlinear least squares 